Volume (1), Nomor (2), Bulan 2021, 64-69

ISSN.

journal homepage: https://mahardhika.or.id/jurnal/index.php/jpdm

\title{
Perbandingan Pengaruh Model Pembelajaran PBL Dan Discovery Learning Terhadap Hasil Psikomotor Passing Bawah Bola Voli
}

\author{
Inang Widigdo \\ ${ }^{1}$ Universitas PGRI Semarang. \\ 1. inangwidig05@gmail.com
}

\section{A R T I C L E I N F O}

\author{
Article history: \\ Received \\ Revised \\ Accepted
}

Keywords: Passing Bawah Bola Voli, PBL \& Discovery Learning, Hasil Psikomotor

\begin{abstract}
A B S T R A C T
The background of this research is that the mastery of basic movements is still low due to the incorrect way of doing the passing technique. The purpose of the study was to determine whether there was effectiveness in the problem based learning learning model on the psychomotor outcomes of volleyball underpassing in class XI students of SMK Negeri 2 Semarang and the discovery learning model on the psychomotor outcomes of volleyball underpassing in students. The research method used in this study is Quasi Experimental Design (quasi-experimental) with the design used in this study is the Noneequivalent Control Group Design. Data collection techniques using tests. The results showed that the hypothesis test was obtained $t$ count $(22.669<29.556)$ which means that the problem based learning and discovery learning models are effective in psychomotor results of passing under volleyball in class XI students of SMK N 2 Semarang. The results of the effectiveness of passing down volleyball with a problem based learning model of 83.06. While the results of the effectiveness of passing down volleyball with the discovery learning model of 89.00. Based on the results above, it is concluded that the discovery learning model is more effective than problem based learning exercises for the effectiveness of volleyball underpassing in class XI students of SMK N 2 Semarang, because from the data the value of the discovery learning model is greater than problem based learning.
\end{abstract}

\begin{abstract}
Abstrak
Penelitian ini dilatarbelakangi penguasaan gerak dasar yang masih rendah dikarenakan cara melakukan teknik passing yang kurang benar. Tujuan penelitian untuk mengetahui apakah ada keefektifan pada model pembelajaran problem based learning terhadap hasil psikomotorik passing bawah bola voli pada siswa kelas XI SMK Negeri 2 Semarang dan model pembelajaran discovery learning terhadap hasil psikomotorik passing bawah bola voli pada siswa. Metode penelitian yang digunakan dalam penelitian ini adalah Quasi Eksprimental Design (eksperimen semu) dengan desain yang digunakan dalam penelitian ini adalah Nonequivalen Control Group Design. Teknik pengambilan data menggunakan tes. Hasil penelitian menunjukan bahwa uji hipotesis diperoleh $t$ hitung $(22,669<29,556)$ yang berarti bahwa model pembelajaran problem based learning dan discovery learning efektif dalam hasil psikomotorik passing bawah bola voli pada siswa kelas XI SMK N 2 Semarang. Hasil keefektifan passing bawah bola voli dengan model pembelajaran problem based
\end{abstract}


learning sebesar 83,06. Sedangkan hasil keefektifan passing bawah bola voli dengan model pembelajaran discovery learning sebesar 89,00. Berdasarkan hasil diatas disimpulkan bahwa model pembelajaran discovery learning lebih efektif daripada latihan problem based learning untuk keefektifan passing bawah bolavoli pada siswa kelas XI SMK N 2 Semarang, karena dari data nilai dari model pembelajaran disecovery learning lebih besar dari problem based learning.

\section{PENDAHULUAN}

Dunia pendidikan mengalami perkembangan seiring dengan perkembangan zaman, begitu pula dengan pendidikan di Indonesia yang terus mengalami perkemnbangan. Perkembangan yang terjadi pada dunia pendidikan di Indonesia saat ini adalah adanya perubahan kurikulum KTSP menjadi kurikulum 2013. Perubahan pada kurikulum tersebut berdampak pada perubahan proses pembelajaran dikelas. Berdasarkan Pemendikbud Nomor 103 tahun 2014 proses pembelajaran pada kurikulum 2013 lebih berpusat pada siswa dengan menggunakan proses pembelajaran langsung dan tak langsung.

Kurikulum 2013 menekankan pada proses pembelajaran yang berbasis pada siswa, sehingga model pembelajaran yang digunakan adalah model pembelajaran yang menuntut siswa untuk lebih aktif dalam proses pembelajaran.

Pendidikan merupakan kebutuhan manusia sepanjang hidup dan selalu berubah mengikuti perkembangan jaman, teknoligi dan budaya masyarakat. Perkembangan dan perubahan pendidkan yang semakin maju menuntut lembaga pendidikan formal atau sekolah dapat membina dan mempersiapkan sumber daya manusia lebih baik lagi dengan cara meningkatkan kualitas pembelajaran yang dilakukan guru. Seorang guru dituntut untuk mengembangkan kemampuan dirinya dengan pengetahuan, keterampilan dan keahlian agar tidak tertinggal oleh perkembangan pendidikan yang semakin maju.

\section{METODE}

Metode yang digunakan pada penelitian ini adalah Quasi Eksprimental Design (eksperimen Semu). Menurut Sugiono dalam (Farid 2018: 44) design ini memiliki kelompok control, tetapi tidak dapat berfungsi sepenuhnya untuk mengontrol variable-variable luar yang mempengaruhi pelaksanaan eksperimen.

Metode ini digunakan untuk pengaruh model pembelajaran problem based learning dan model pembelajaran discovery learning terhadap hasil belajar passing bawah di SMK N 2 Semarang. Sedangkan penelitian ini menggunakan desain Nonequivalen Control Group Design. Desain ini hampir sama pretest-posttest group desain, hanya dengan desain ini kelompok eksperimen dan kelompok control tidak dipilih secara random. 


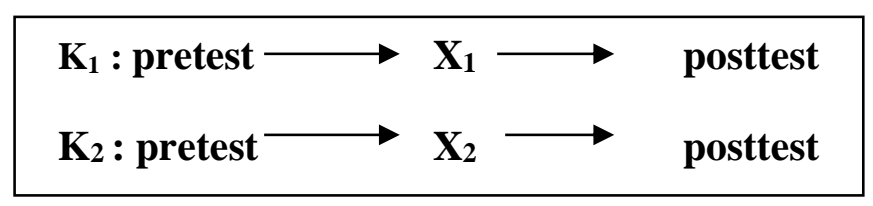

Keterangan:

$\mathrm{K}_{1}$ : kelas dengan penerapan model pembelajaran problem based learning(kelas eksperimen).

$\mathrm{K}_{2}$ : kelas dengan penerapan model pembelajaran discovery learning (kelas eksperimen).

$\mathrm{X}_{1}$ : penerapan model pembelajaran problem basd learning.

$\mathrm{X}_{2}$ : penerapan model pembelajaran discovery learning.

\section{HASIL DAN PEMBAHASAN}

1. Pengaruh Model Pembelajaran Problem Based Learning Terhadap Hasil Belajar Psikomotor Passing Bawah Siswa Kelaas XI SMK Negeri 2 Semarang.

Model pembelajaran problem based learning merupakan model pembelajaran dimana peserta didik mengerjakan permasalahan yang otentik dengan maksud untuk menyusun pengetahuaan mereka sendiri, mengembangkan inkuiri dan keterampilan berpikir tingkat lebih tinggi, mengembangkan kemandirian, dan percaya diri.

Berdasarkan hasil penelitian pemberian model pembelajaran problem based learning berpengaruh terhadap psikomotor pada pembelajaran passing bawah bola voli meningkat, dikarenakan peserta didik dapat belajar melakukan gerak dasar dengan cara mengumpulkan informasi dan memecahkan masalah. Dalam penelitian ini model pembelajaran problem based learning diterapkan pada siswa kelas XI BDP 1 sebanyak 36 orang.

Hasil penelitian ini didukung oleh penelitian terdahulu yang dilakukan oleh Suzianto dan Damanik mengenai "penerapan model problem based learning dalam meningkatkan hasil belajar passing bawah bola voli siswa kelas VIII-2 SMP Negeri 27 Medan tp. 2018/2019. Menyimpulkan bahwa Guru Pendidikan Jasmani SMP Negeri 27 Medan dapat menerapkan metode Problem Based Learning dan modifikasi bola melalui materi yang disesuaikan karena hal ini dapat menciptakan pembelajaran aktif dan mengembangkan cara berfikir kritis siswa melalui pemecahan masalah.

2. Pengaruh Model Pembelajaran Discovery Learning Terhadap Hasil Belajar Psikomotor Passing Bawah Siswa Kelaas XI SMK Negeri 2 Semarang

Model pembelajaran discovery learning merupakan model pembelajaran yang menemukan konsep melalui serangkaian data atau informasi yang diperoleh melalui pengamatan dan percobaan. 
Peningkatan model pembelajaran discovery learning terhadap hasil psikomotor passing bawah bola voli karena peserta didik belajar melakukan teknik dasar dengan cara mengamati video yang ditampilkan melalui microsoft teams. Dalam penelitian ini model pembelajaran discovery learning diterapkan pada siswa kelas XI UPW 1 sebanyak 36 orang.

Hasil penelitian ini didukung oleh penelitian terdahulu yang dilakukan oleh Fitriyah, Ali Murtadlo, dan Rini Warti (2017) mengenai "pengaruh model pembelajaran discovery learning terhadap hasil belajar matematika siswa MAN model kota Jambi”. Menyimpulkan bahwa hasil belajar matematika siswa yang menggunakan model discovery learning lebih baik dari hasil belajar matematika siswa yang tidak menggunakan model discovery learning (model konvensional).

3. Perbedaan Pengaruh Model Pembelajaran Problem Based Learning dan Discovery Learning Terhadap Hasil Belajar Psikomotor Passing Bawah Siswa Kelaas XI SMK Negeri 2 Semarang

Model pembelajaran yang diterapkan dalam hasil belajar psikomotor passing bawah bola voli siswa kelas XI SMK Negeri 2 Semarang adalah problem based learning untuk kelas XI BDP 1 dan discovery learning untuk kelas XI UPW 1. Untuk mengetahui perbedaan pengaruh hasil belajar dengan model pembelajaran problem based learning dan discovery learning pada teknik passing bawah bola voli pada siswa kelas XI SMK Negeri 2 Semarang dan untuk mengetahui model pembelajaran manakah yang lebih efektif antara model pembelajaran problem based learning dan model pembelajaran discovery learning terhadap hasil belajar psikomotor passing bawah bola voli pada siswa kelas XI SMK Negeri 2 Semarang, maka dilakukan analisis data dengan independent sample t-test.

Hasil belajar psikomotor passing bawah bola voli dengan model pembelajaran discovery learning lebih efektif karena dengan diberikan perlakuan model discovery learning siswa dapat melakukan mengamati cara melakukan passing bawah, dikarenakan jenis model pembelajaran yang diberikan berupa mengamati video passing bawah sehingga proses pembelajaran sangat jelas dan siswa paham akan materi yang telah disampaikan. Sedangkan dalam perlakuan model pembelajaran problem based learning masih kurang paham dikarenakan siswa disuruh menyusun pengetahuan mereka sendiri sekaligus memecahkan masalah.

Penelitian ini didukung oleh penelitian terdahulu yang dilakukan oleh Reza Eko Ivanto 2015 di Universitas Negeri Surabaya yang berjudul "Penerapan Model Pembelajaran Discovery Learning pada Kurikulum 2013 terhadap Hasil Belajar Passing Bawah pada siswa kelas XI SMA Negeri 1 Tambakboyo Tuban" dan Penelitian yang dilakukan oleh Suzianto dan Suryadi Damanik 2019 di Universitas Negeri Medan yang berjudul "Penerapan Model Problem Based Learning dalam 
meningkatkan hasil belajar Passing Bawah Bola Voli siswa kelas VIII-2 SMP Negeri Medan Tahun Pelajaran 2018/2019".

\section{KESIMPULAN}

Berdasarkan hasil penelitian dan analisis data yang telah dilakukan oleh penulis, dapat diperoleh kesimpulan sebagai berikut :

1. Ada pengaruh yang signifikan model pembelajaran problem based learning terhadap hasil belajar psikomotor passing bawah bola voli kelas XI SMK Negeri 2 Semarang.

2. Ada pengaruh yang signifikan model pembelajaran discovery learning terhadap hasil belajar psikomotor passing bawah bola voli kelas XI SMK Negeri 2 Semarang.

3. Model discovery learning lebih efektif dalam meningkatkan hasil belajar psikomotor passing bawah bola voli kelas XI SMK N 2 Semarang.

\section{DAFTAR PUSTAKA}

Amin, S. (2017). "Pengaruh model pembelajaran problem based learning terhadap kemampuan berpikir kritis dan hasil belajar geografi". JPG (Jurnal Pendidikan Geografi).4(3) 25-36.

Fitriyah, Murtadlo, A\& Warti, R. (2017). "Pengaruh model pembelajaran discovery learning terhadap hasil belajar matematika siswa MAN model Kota Jambi". ejournal. 2 (9) 108-112.

Heryadi, D\& Hadiana, O. (2017). "Perbandingan model discovery learning dengan model peer teaching (tutor sebaya) terhadap kemampuan teknik dasar passing bawah dalam permainan bola voli pada kelas XI SMA Negeri 1 Ciawigebang Kabupaten Kuningan".

Ivanto, R. E \& Hartati, S. C. Y. (2015)."Penerapan model pembelajaran discovery learning pada kurikulum 2013 terhadap hasil belajar passing bawah (Studi Pada Siswa Kelas XI SMA Negeri 1 Tambakboyo Tuban)". Jurnal Pendidikan Olahraga dan Kesehatan,2 (3) 330-336.

Kristin, F\& Rahayu, D. (2016). "Pengaruh penerapan model pembelajaran discovery learning terhadap hasil belajar ips pada siswa kelas 4 SD". Scholaria. 1 (6) 84-92.

Kusuma, I. W. W., Wahjoedi \& Wijaya, I. M. K. (2017). "Pengaruh model pembelajaran berbasis masalah (problem based learning) terhadap hasil belajar bola voli". e-Journal. 2(8).

Mukholid, A. (2013). Penjasorkes 1. Bogor: Yudhistira.

Pratiwi, I. A. Wahjoedi, \& Satyawan, I. M. (2017). "Pengaruh model pembelajaran berbasis masalah terhadap hasil belajar teknik dasar passing bola voli pada siswa kelas VIII SMP Negeri 1 Singaraja tahun pelajaran 2016/2017". E-Journal. 8(2) 1-10. 
Perbandingan Pengaruh Model Pembelajaran PBL Dan Discovery Learning Terhadap Hasil Psikomotor Passing Bawah Bola Voli_Inang Widigdo

Rahmani, M. (2014). Buku super lengkap olahraga. Jakarta Timur: Dunia Cerdas.

Slameto. (2010).Belajar \& faktor-faktor yang mempengaruhinya. Jakarta: Rineka Cipta.

Sugiono (2016). Metode penelitian kuantitatif, kualitatif, dan kombinasi (mixed methods).

Supiandi, M. I\& Julung, H. (2016) "Pengaruh model problem based learning (PBL) terhadap kemampuan memecahkan masalah dan hasil belajar kognitif siswa biologi SMA".Jurnal Pendidikan Sains. 2 (4) 60-64.

Suzianto \& Damanik, S. (2019). "Penerapan model problem based learning dalam meningkatkan hasil belajar passing bawah bola voli siswa kelas VIII-2 SMP Negeri 27 Medan TP.2018/2019". Jurnal Ilmu Keolahragaan. 18(1) 14-24.

Virgiana, A \& Wasitohadi. (2015). "Efektifitas model problem based learning berbantuan media audio visual ditinjau dari hasil belajar ipa siswa kelas 5SDN 1 Gadu Sambong-Blora semester 2 tahun 2014/2015".Scholaria. 100-118.

Wulandari, B \& Surjono, H. D. (2013). "Pengaruh problem-based learning terhadap hasil belajar ditinjau dari motivasi belajar PLC di SMK". Jurnal Pendidikan Vokasi.3(2) 178-191. 